\title{
SPÓR O GENOCENTRYZM W FILOZOFII BIOLOGII
}

\begin{abstract}
Streszczenie. Źródeł koncepcji genocentrycznej należy dopatrywać się w dynamicznym rozwoju XIX- i XX-wiecznej genetyki - zwłaszcza współczesnej syntezy ewolucyjnej oraz genetyki molekularnej. Za ideą tą stoi teza, iż w naukach biologicznych wyjaśnienia odwołujące się do czynników genetycznych są uprzywilejowane; przy tym istotnym założeniem idei genocentrycznej w ramach genetyki molekularnej jest to, że geny oraz kod genetyczny pełnią szczególną rolę w determinowaniu rozwoju organizmu.

Chociaż stanowisko genocentryczne jest jednym z fundamentów współczesnej teorii ewolucji, to przez długi czas nie podejmowano na tym gruncie problematyki biologii rozwoju. W związku z tym w ostatnich latach można dostrzec zwrot w stronę nurtu alternatywnego, wykazującego istotność uwzględnienia czynników poza-genetycznych w wyjaśnianiu zjawisk i procesów biologiczno-rozwojowych.

Najistotniejsze w tym kontekście są argumenty i idee stojące za odrzuceniem specjalnej roli genów, zwłaszcza na gruncie ewolucyjnej biologii rozwoju; kontekst evo-devo wydaje się interesujący ze względu na ambicję integracji biologii rozwojowej i biologii ewolucyjnej.

Słowa kluczowe: filozofia przyrody, filozofia nauki, filozofia biologii, genetyka, genocentryzm, evo-devo
\end{abstract}

1. Wprowadzenie. 2. Źródła genocentryzmu. 3. Czym jest genocentryzm? 4. Problemy genocentryzmu. 5. Genocentryzm w kontekście Evo-Devo. 6. Evo-Devo ${ }_{G E N}$. 7. Developmental System Theory. 8. Zakończenie.

\section{WPROWADZENIE}

Problem genocentryzmu jest w literaturze filozoficznej dyskutowany przynajmniej na dwóch frontach: klasycznej genetyki w perspektywie dawkinsowskiej metafory samolubnych genów oraz genetyki molekularnej w kontekście wyróżnionej roli materiału genetycznego. W niniejszym tekście pojawi się próba ustalenia źródeł genocentryzmu i momentu rozejścia się konceptualizacji pojęcia genu opartego na metaforze samolubnych genów w ramach genetyki klasycznej 
oraz teoretycznych podstawach genetyki molekularnej. Zwłaszcza w kontekście tej drugiej dyscypliny kontrowersje wokół pojęcia genu stworzyły wiele problematycznych kwestii w obrębie genocentryzmu.

W pierwszej części tego tekstu rozważone zostaną podstawowe konceptualne źródła tezy o genocentryzmie na gruncie genetyki. Rozpatrzone zostaną pod tym względem ustalenia dokonane przez Augusta Weismanna odnośnie struktury komórkowej; od początku bowiem doszukiwano się tam jakichś specjalnych jednostek determinujących rozwój organizmów żywych. Dla A. Weismanna była to przykładowo plazma zarodkowa, dla Thomasa H. Morgana scharakteryzowane przez Wilhelma Johannsena geny. Właśnie ta prosta i dyskretna jednostka genu powiązana $z$ dziedzicznymi fenotypami zapanowała w klasycznej genetyce, dając podstawy pod neodarwinowską genetykę populacyjną. Sukces określenia fizycznej i chemicznej charakterystyki genu został uznany dopiero dzięki odkryciom dokonanym przez Jamesa Watsona, Francisa Cricka, Rosalind Franklin oraz Maurice'a Wilkinsa. To nowe spojrzenie doprowadziło do fundamentalnej zmiany w postrzeganiu genów. Poprzez jasno zdefiniowany model struktury fizyko-chemicznej DNA zaczęto wydzielać odpowiednie fragmenty, które nazwano genami. Jednakże to wydarzenie w rozwoju nauk biologicznych zapoczątkowało pojawienie się anomalii i komplikacji w uznawanej wcześniej za oczywistą roli DNA.

Następnie zostanie opisana główna teza genocentryzmu na gruncie filozofii biologii oraz jej istotne wyróżniki dla ustalenia linii sporu. W kolejnej części zostaną wskazane również głosy krytyczne wobec koncentrowania się na wybranych strukturach genetycznych. Wątpliwości takie zostały podniesione przez szereg teoretyków i filozofów biologii. Poczynając od problematycznych prób zdefiniowania genu na poziomie molekularnym ${ }^{1}$, anomaliach obserwowanych

1 Por. np. C.K. Waters, Genes Made Molecular, Philosophy of Science 61(1994)2, 163-85. 
w kontekście neoklasycznej ${ }^{2}$ koncepcji genu ${ }^{3}$ czy też zastrzeżeniach związanych z zasadnością przyjmowania specjalnej roli genów ${ }^{4}$.

Te kwestie dały podstawy pod krytyczne, wobec stanowiska genocentrycznego, alternatywne propozycje związane z podejściem systemowym, zwłaszcza w kontekście evo-devo. W dalszej części tekstu zaprezentowana zostanie część tych krytycznych argumentów wobec stanowiska genocentrycznego.

Celem niniejszego tekstu jest zanalizowanie sporu dotyczącego tezy genocentryzmu oraz stanowisk krytycznych wobec tej koncepcji (systemowych). Zagadnienie to jest istotne dla określenia znaczenia oraz roli materiału genetycznego w filozoficznych interpretacjach z zakresu nauk biologicznych. Kontrowersje dotyczące genocentryzmu i alternatywnych propozycji zostaną omówione szczególnie w zakresie ewolucyjnej biologii rozwoju.

\section{2. ŹRÓDŁA GENOCENTRYZMU}

Sformułowania genocentryzmu można upatrywać w trzech konceptualizacjach z zakresu genetyki. Chronologicznie było to sformułowanie tzw. bariery Weismanna, określenie teoretycznych podstaw neodarwinizmu wraz z rozwojem genetyki populacyjnej oraz wskazanie przez Francisa Cricka centralnego dogmatu genetyki molekularnej i hipotezy sekwencyjnej. Te trzy etapy wydają się w równym stopniu istotne dla umocowania koncepcji genocentrycznej, aczkolwiek prowadzą także do różnych kwestii problemowych w sporze o znaczenie genów.

2 Nazwy tej używa m.in. P. Portin, The Concept of the Gene: Short History and Present Status, The Quarterly Review of Biology 68(1993)2, 173-223.

3 Por. np. R.M. Burian, On Conceptual Change in Biology: the Case of the Gene, w: in Evolution at a Crossroads, red. D.J. Depew, B.H. Weber, Cambridge, Massachusetts 1985, 21-42.

4 Por. np. J. S. Robert, Embryology, Epigenesis and Evolution, Cambridge 2004. 
A. Weismann, niemiecki biolog przełomu XIX i XX wieku, przyczynił się w znaczący sposób do rozwiązania problemu dziedziczności na gruncie darwinowskiej teorii ewolucji. Ogromnym problemem darwinizmu przez długi czas pozostawała kwestia powstawania zmienności i dziedziczenia zmian. Hipoteza pangenezy zaproponowana przez Ch. Darwina z trudnością mogła zostać wskazana jako podstawa do wyjaśnienia tych zjawisk (zwłaszcza przez gruntownie hipokratejskie powinowactwo) ${ }^{5}$. Koncepcja A. Weismanna oparta została na postulacie istnienia dwóch odrębnych linii komórkowych: somatycznych oraz generatywnych. Zgodnie z tą intuicją, wyłącznie gamety mają znaczenie w kontekście dziedziczności, zatem wszelka zmienność w kolejnych pokoleniach związana jest z modyfikacją tej linii komórkowej. Istotnym składnikiem gamet miała być plazma zarodkowa, będąca w założeniu pewną strukturą fizyko-chemiczną, determinującą ${ }^{6}$ wzrost komórek somatycznych w procesie rozwoju osobniczego. Zmiany w obrębie komórek somatycznych nie miały mieć żadnego wpływu na dziedziczenie cech, wszelka zaś zmiana w postulowanej plazmie somatycznej znikać miała wraz ze śmiercią jednostkowego osobnika. Tym prostym zabiegiem, rozdzielenia dwóch linii komórkowych ${ }^{7}$, udało się podważyć koncepcje lamarckowskie - dziedziczenia cech nabytych. Idea bariery A. Weismanna stała się jednym $\mathrm{z}$ fundamentów genetyki i teorii dziedziczenia pierwszych dekad XX wieku, zwłaszcza w zakresie badań chromosomów.

5 Zob. U. Deichmann, Gemmules and Elements: on Darwin's and Mendel's Concepts and Methods in Heredity, w: Darwinism, Philosophy, and Experimental Biology, red. U. Deichmann, A.S. Travis, Dordrecht 2011, 31-58.

6 Wydaje się, że pojawia się tutaj hipoteza proto-genowa; rzecz jasna charakterystyka proponowana przez A. Weismanna daleka jest od adekwatności, jednakże pewne istotne intuicje wiązane z teorią chromosomalną Thomasa Morgana zostają już uchwycone.

7 Idea ta nie była rzecz jasno czysto spekulatywna; wzmożone badanie układów komórkowych miało miejsce wraz z rozwojem mikroskopii i w czasach A. Weismanna pewne struktury komórkowe (np. chromosomy) były znane - problemem przez długi czas pozostawało ustalenie funkcji tych struktur, na co odpowiedzią była właśnie koncepcja plazmy zarodkowej. 
Jednym z istotniejszych przewidywań na gruncie tej teorii było to, że gamety posiadają jedynie połowę chromosomów obecnych w komórkach somatycznych i dopiero połączenie komórki jajowej i plemnika przywraca ich standardową liczbę 8 .

Chociaż sama koncepcja plazmy zarodkowej stosunkowo szybko została zarzucona z pewnych praktycznych i merytorycznych względów (m.in. ponownego odkrycia prac Gregora Mendla) ${ }^{9}$, to kierunek badań został wyznaczony. Poznanie struktur komórkowych i ustalenie ich znaczenia dla rozwoju organizmu oraz uzupełnienia darwinizmu teorią dziedziczenia.

Wspomniane ponowne odkrycie prac G. Mendla, wprowadzenie przez Wilhelma Johannsena pojęć genu, genotypu i fenotypu oraz badania Thomasa H. Morgana na Drosophila melanogaster przyniosły pozytywne wyniki w zakresie powiązania dziedziczności z darwinizmem. Zwieńczeniem tego była opracowana na przestrzeni lat 19201940 genetyka populacyjna; to także moment powolnego rozwodu biologii ewolucyjnej z biologią rozwoju. Wprowadzona zostaje idea genów, jako jednostek odpowiedzialnych za dziedziczenie cech - jeszcze bez odwoływania się do ich fizycznej struktury (jedynie położenia na chromosomach), lecz łączenie ich z występowaniem określonych fenotypów. Pozwoliło to na stworzenie matematycznych modeli rozkładu genów (resp. alleli) w populacjach. Na bazie pojęcia genu wykorzystywanego w tej dyscyplinie Richard Dawkins skonstruował swoją kluczową metaforę samolubnych genów, ugruntowując tym samym perspektywę genocentryczną w biologii ewolucyjnej.

W latach 1940-1950 głównym celem stało się odniesienie pojęcia genu do jakiejś fizycznej struktury; wskazanie genu na chromosomie było zaledwie połowicznym sukcesem, bowiem nie wyjaśniało w precyzyjny sposób procesów replikacji i ekspresji materiału genetycznego.

8 L.N. Magner, A History of the Life Sciences, New York 2002, 395-396.

9 Szerzej pisze o tym E. Mayr (zob. E. Mayr, To jest biologia, tłum. z ang. J. Szacki, Warszawa 2002.). 
Poczynając od badań, m.in. Hermana J. Mullera, Maxa Delbrücka, Jacquesa Monoda oraz François Jacoba (i wielu innych zespołów badawczych), starano się klasyczne pojęcie genu umieścić w kontekście molekularnym ${ }^{10}$. Niemniej dopiero James Watson i Francis Crick, korzystając z badań Rosalind Franklin i Maurice’a Wilkinsa, zdołali wskazać odpowiednią strukturę fizyko-chemiczną - podwójną helisę DNA. To umożliwiło wypracowanie odpowiedniej konceptualizacji genu.

Najistotniejsza teza, na której opiera się genocentryzm, wyrażona została później przez Francisa Cricka jako centralny dogmat genetyki molekularnej (Central Dogma of molecular biology), który autor opisuje następująco: "gdy informacja przejdzie do białka nie jest możliwe by się z niego wydostała. Dokładniej ujmując, transfer informacji $\mathrm{z}$ kwasu nukleinowego do innego kwasu nukleinowego lub z kwasu nukleinowego do białka może zajść ${ }^{11}$, lecz transfer [informacji - przyp. A.A.Z.] z białka do białka lub z białka do kwasu nukleinowego jest niemożliwy. Informacja oznacza tutaj ściśle zdeterminowaną sekwencję, bądź to zasad w kwasie nukleinowym, bądź to reszt aminokwasowych białka"12.

Obok centralnego dogmatu, F. Crick sformułował także hipotezę sekwencyjną, dotyczącą sposobu ekspresji genów; głosiła ona, że fragment kwasu nukleinowego podlega ekspresji wyłącznie według bazowej kolejności nukleotydów i jest prostym kodem dla

10 L.N. Magner, A History of the Life Sciences, New York 2002, 417- 437.

11 W późniejszym artykule Central Dogma of Molecular Biology F. Crick uwzględnił także możliwość transferu informacji DNA $\rightarrow$ RNA (zob. F.H.C. Crick, Central Dogma of Molecular Biology 227(1970), 561-63).

12 Tenże, On Protein Synthesis, Symposia of the Society for Experimental Biology 12(1958), 153 (tłum. A.A.Z.): „once 'information' has passed into protein it cannot get out again. In more detail, the transfer of information from nucleic acid to nucleic acid, or from nucleic acid to protein may be possible, but transfer from protein to protein, or from protein to nucleic acid is impossible. Information means here the precise determination of sequence, either of bases in the nucleic acid or of amino acid residues in the protein". 
sekwencji aminokwasów białka wyjściowego ${ }^{13}$. Propozycja ta ugruntowała pewną wizję pojęcia genu jako wypełnioną empiryczną treścią klasyczną koncepcją genu, obowiązującego w klasycznej genetyce, sugerując wraz $\mathrm{z}$ tym prosty mechanizm ich działania - ekspresji i replikacji (w dużym uproszczeniu, dla ekspresji schemat przebiega w sposób następujący: $D N A \stackrel{\text { transkrypcja }}{\longrightarrow} R N A \stackrel{\text { translajaja }}{\longrightarrow}$ biatko, zaś w przypadku replikacji: $D N A \rightarrow R N A)^{14}$.

$\mathrm{Na}$ podstawie badań F. Cricka i J. Watsona została zrekonstruowana, na gruncie filozofii biologii, neoklasyczna koncepcja genu ${ }^{15}$. Gen jako jednostka dziedziczności został w tej koncepcji umocowany w fizycznym obiekcie - DNA. Wcześniej geny wskazywane były co najwyżej na chromosomach, charakteryzowane jako teoretyczne konstrukty $-\mathrm{w}$ rozumieniu W. Johannsena jednostki ułatwiające po prostu dokonywanie obliczeń prawdopodobieństwa odziedziczenia interesujących cech.

Opisana przez A. Weismanna wyjątkowość komórek generatywnych, następnie wskazanie mechanizmów dziedziczenia przez Thomasa H. Morgana, umieściły geny w centralnym punkcie nauk biologicznych. Natomiast model DNA J. Watsona i F. Cricka przeniósł problem na grunt fizykalno-chemiczny. W taki sposób postrzeganie genów jako specjalnych przyczyn zmienności zostało umocowane także w literaturze filozoficznej ${ }^{16}$.

13 Tamże, 153

14 F. Crick nie rozważał w tym modelu kwestii obróbki posttranskrypcyjnej RNA, obróbki posttranslacyjnej białek i innych istotnych zjawisk molekularnych.

15 P. Portin, The Concept of the Gene: Short History and Present Status, The Quarterly Review of Biology 68(1993)2, 173-223.

16 Zob. A. Rosenberg, Defending Information-Free Genocentrism, History \& Philosophy of the Life Sciences 27(2005)3, 345-59; A. Rosenberg, Darwinian Reductionism, Chicago, Illinois 2006. 


\section{CZYM JEST GENOCENTRYZM?}

Teza genocentryczna zaistniała głównie na dwóch polach: badania mechanizmów biologii ewolucyjnej rozumianej już poprzez pryzmat metafory samolubnych genów Richarda Dawkinsa oraz genetyki molekularnej, gdzie zaczęto rozważać przyczynową rolę genów w procesie rozwojowym. Oba wymienione stanowiska są rzecz jasna powiązane - poprzez Darwinowski paradygmat ewolucyjny - jednakże dotyczą w pewnym stopniu odrębnych sporów.

W przypadku metaforyki R. Dawkinsa określić można dwa zasadnicze problemy: kwestię realności genów ${ }^{17}$ na gruncie genetyki populacyjnej oraz tego, na jakim poziomie organizacji działa dobór naturalny ${ }^{18}$. Zagadnienia te są wciąż mocno dyskutowane, zwłaszcza w perspektywie coraz mocniejszej integracji dyscyplin zajmujących się rozwojem biologicznym i ewolucją układów żywych. W kontekście niniejszego tekstu problemy te nie będą mocniej rozwijane, ponieważ znaczenie Dawkinsowego genocentryzmu nie wpływa bezpośrednio na stanowisko w ramach biologii molekularnej. Jest tak w głównej mierze dlatego, że definicja genu przyjęta przez R. Dawkinsa nie odnosi się do tych obiektów na poziomie molekularnym. Propozycja przedstawiona w Samolubnym genie, koncentruje się na koncepcji replikatora, nie zaś strukturze fizyko-chemicznej ${ }^{19}$.

W zakresie genetyki molekularnej zagadnienie roli genów dotyczy w głównej mierze przyczynowego wpływu na rozwój osobniczy oraz

17 Problem ten wyraźnie zaznaczył James Gleick, pisząc: „Jeśli geny zasługują na miano mistrzów przetrwania, to raczej nie mogą być fragmentami kwasu nukleinowego. Takie związki są nietrwałe. Powiedzenie, że replikator potrafi przetrwać wieki, jest równoważne z określeniem tegoż replikatora jako wszystkich jego kopii potraktowanych jako całość, coś jednostkowego. Wobec tego gen się »nie starzeje się", oświadczył Dawkins”. J. Gleick, Informacja, tłum. z ang, G. Siwek, Kraków 2012, 283.

18 Spór dotyczy tego czy mechanizmy ewolucyjne funkcjonują na poziomie genów, osobników, czy też grup (populacji lub gatunków) (por. np. B. Garvey, Philosophy of Biology, Stocksfield 2007, 29-39).

19 R. Dawkins, Samolubny gen, tłum. z ang. M. Skoneczny, Warszawa 2012. 
działania molekularnych mechanizmów ewolucyjnych. W związku z tym podnoszona jest kwestia uzasadnienia dla prowadzenia badań nad rozwojem i ewolucją z perspektywy centralnej roli genów. Stanowisko genocentryczne związane jest zatem z pewną tezą stwierdzającą, iż podstawowe jednostki dziedziczenia, tj. geny, grają centralną rolę w działaniu mechanizmów rozwojowych i ewolucyjnych. Można również wskazać złagodzoną wersję dotyczącą tej propozycji, tj. że zjawiska biologiczne związane $\mathrm{z}$ dziedziczeniem, rozwojem oraz molekularnymi mechanizmami ewolucyjnymi należy wyjaśniać z perspektywy specjalnej roli genów ${ }^{20}$ (stoi za tym milczące założenie, że geny należy właśnie przyczynowo wyróżnić w celu adekwatnego wyjaśnienia).

Ujaśniając jeszcze kwestię omawianego stanowiska należy zaznaczyć, że błędne jest traktowanie genocentryzmu synonimicznie $z$ genetycznym determinizmem. Ta druga propozycja wyraża pogląd, iż możliwe jest jedno-jednoznaczne wskazanie jednostki dziedziczenia lub grupy takich jednostek odpowiedzialnych za pewną cechę fenotypową (bardzo szeroko rozumianą). Tego typu podejście reprezentowane jest niekiedy w dyskursie bioetycznym, nazbyt upraszczającym sytuację problemową ${ }^{21}$. Przyjęta zostaje narracja korzystająca

20 Nie wikłając się w problematykę samego definiowania terminu gen, przyjmować się będzie, że na gruncie genetyki populacyjnej gen jest to po prostu pewna jednostka wpływająca na zmienność w populacji, natomiast na gruncie genetyki molekularnej gen można rozumieć w sposób (i) tradycyjny (neoklasyczny), (ii) nominalny (czyli to wszystko, co badacze są skłonni uznać za gen) lub (iii) postgenomiczny (koncepcja rozszerzająca pojęcie genu na związki między strukturami genetycznymi i pozagenetycznymi). Propozycje (ii) i (iii) wysunęli Paul Griffiths, Karola Stotz oraz Rob Knight (K.C. Stotz, P.E. Griffiths, R. Knight, How Biologists Conceptualize Genes: an Empirical Study, Studies in History and Philosophy of Science Part C 35(2004)4, 647-73; P.E. Griffiths, K. Stotz, Gene, w: The Cambridge Companion to the Philosophy of Biology, red. D.L. Hull, M.E. Ruse, Cambridge 2007, 85-102).

21 Przykładowo, Jürgen Habermas, w swoim alarmistycznym tekście „Przyszłość natury ludzkiej”, wydaje się odwoływać do takiego rozumienia relacji gen-cecha; jego argumentacja odwołuje się do powiązania „niezmanipulowanego dziedzictwa genetycznego" z pojęciem „tożsamości gatunkowej”, lecz zwłaszcza kiedy pisze on o „genetycznych modyfikacjach 
z hipotezy sekwencyjnej. Określa się, że istnieje jakaś jasna i jedno-jednoznaczna relacja pomiędzy genem X (lub genami XYZ) a cechą A. Takie uproszczone postawienie sprawy fałszuje złożony obraz dziedziczenia, pomija już podstawową trudność związaną chociażby plejotropią, nie wspominając o bardziej złożonych mechanizmach (genetycznych i pozagenetycznych) różnicujących cechy dziedziczne. Genetyczny determinizm postrzegać należy zatem jako stanowisko niezależne względem genocentryzmu i całkowicie błędne poprzez nadmierne uproszczenie problematyki. Ponadto sugerowanie genetycznego determinizmu zwolennikom genocentryzmu wydaje się być nieuczciwym zabiegiem. Zwolennicy tego drugiego stanowiska nie negują istotności procesów pozagenetycznych, jedynie wyróżniają elementy DNA.

Genocentryzm, traktowany w kontekście uzasadnienia dla wyjaśniania zjawisk genetycznych, nie jest także tożsamy z molekularnym redukcjonizmem, chociaż w pewnym zakresie stanowiska te wzajemnie się wspierają; redukcjonizm w genetyce był historycznie propozycją dwuetapową. Na początku dotyczył redukcji klasycznej genetyki do genetyki molekularnej (czasem również spekulowano nad bardziej radykalną redukcją: do fizyki i chemii ${ }^{22}$ ). Tego typu modele redukcji interteoretycznej konstruowane były w kontekście genetyki, m.in. przez Kennetha F. Schaffnera; założona była poprawność neoklasycznej koncepcji genu, a w związku $\mathrm{z}$ tym postulowano stosunkowo prostą przekładalność pojęcia genu w sensie klasycznym do genu $\mathrm{w}$ sensie molekularnym ${ }^{23}$. Wraz z załamaniem się modeli redukcji

cech" wydaje się odwoływać do takiego uproszczonego rozumienia determinizmu genetycznego, J. Habermas, Przyszłość natury ludzkiej, tłum. z niem. M. Łukasiewicz, Warszawa 2003, 22-29.

22 Por. J.G. Kemeny, P. Oppenheim, On Reduction, Philosophical Studies 7(1956)1, 6-19; K.F. Schaffner, Approaches to Reduction, Philosophy of Science 34(1967), 137-47.

23 Zob. K.F. Schaffner, Discovery and Explanation in Biology and Medicine, Chicago 1993. 
interteoretycznej ${ }^{24}$ zaczęto rozważać zagadnienie redukcji eksplanacyjnej. Taką mniej absolutystyczną propozycję wyraził przykładowo Sahotra Sarkar, postulując, iż jednostkowe wyjaśnienie odwołujące się do genu w sensie klasycznym można przełożyć na jednostkowe wyjaśnienie na poziomie molekularnym ${ }^{25}$ - dyskusyjna pozostaje ekstrapolacja takiego wyjaśnienia na inne przypadki. Redukcjonizm molekularny należy rozumieć jako ogólniejszą tezę, wymagającą jedynie, aby wyjaśnienia dowolnego zjawiska biologicznego odwoływały się do opisu molekularnego. Nie jest konieczne odniesienie do jakiegoś konkretnego obiektu molekularnego (np. DNA) lub zjawiska, lecz dowolnego obiektu lub zjawiska molekularnego, które w sposób możliwie adekwatny i wyczerpujący wyjaśnia obserwowane zjawisko ${ }^{26}$. Podana definicja jest elastyczna względem różnych propozycji genocentrycznych (nie-molekularnych, jak propozycja R. Dawkinsa ${ }^{27}$, oraz molekularnych), a także nie-genocentrycznego redukcjonizmu molekularnego (np. w kwestii wyjaśnienia dziedziczenia wewnątrzpokoleniowego przez odwołanie się do molekularnych mechanizmów epigenetycznych).

24 Rozległą krytykę zagadnienia redukcji genetyki klasycznej do molekularnej rozważali przykładowo D.L. Hull, Informal Aspects of Theory Reduction, w: PSA 1974, red. R.S Cohen et al., Dordrecht 1976, 653-70; U.C. Moulines, Ontological Reduction in the Natural Sciences, w: Reduction in Science, red. W. Balzer, D.A. Pearce, H.-J. Schmidt, Dordrecht 1984, 51-70; E. Mayr, Toward a New Philosophy of Biology, Cambridge, Massachusetts 1988, 8-23, a także ogólniejsze zastrzeżenia na gruncie tezy o niewspółmierności wyraził P. Feyerabend, Explanation, Reduction, and Empiricism, w: Scientific Explanation, Space, and Time, red. H. Feigl, G. Maxwell, Minneapolis 1962, 28-97.

25 Zob. S. Sarkar, Genetics and Reductionism, Cambridge 1998, 39-70.

26 P.M. Rosoff, A. Rosenberg, How Darwinian Reductionism Refutes Genetic Determinism, Studies in History and Philosophy of Science Part C 37(2006)1.

27 R. Dawkins definiuje gen nie poprzez strukturę fizyko-chemiczną, lecz, za G.C. Williamsem, jako fragment chromosomu: „dowolna część materiału chromosomalnego, która może trwać przez wystarczająco wiele pokoleń po to, by stać się jednostką doboru naturalnego. (...) gen jest replikatorem o dużej wierności kopiowania". R. Dawkins, Samolubny gen, tłum. z ang. M. Skoneczny, Warszawa 2012, 75. 
Alexander Rosenberg i Philipp M. Rosoff proponują następującą analogię ${ }^{28}$, porównującą działanie mechanizmów genetycznych i pozagenetycznych do sytuacji budowy ceglanego muru przez czeladnika i mistrza murarskiego:

„Ostatni [mistrz murarski; przyp. A.A.Z.] kieruje wszelkimi aspektami projektu, podczas gdy pierwszy [czeladnik; przyp. A.A.Z.] wykonuje całą robotę uwzględniając instrukcję mistrza murarskiego. To mistrz bierze na siebie wszelkie zasługi, jak i winę za efekt końcowy budowanego muru; wszyscy inni uczestnicy projektu po prostu wykonują polecenia. O ile oczywiście mur nie był budowany na gruncie niedostosowanym do budowania ceglanych ścian, co oznacza, że osoba kierująca budową bierze na siebie winę. Oraz oczywiście jeżeli jest tam główny wykonawca, który wybrał mistrza murarskiego, albo ktoś kto dostarczył cegły bez zgody mistrza murarskiego, a następnie mówi mu jak lepiej zaprojektować mur, wtedy być może pochwała lub wina przypada tej osobie. W naszej historyjce cegły oraz ziemia, na której budowany jest mur, oznaczają środowisko, geny zaś grają wszelkie inne role"29.

W związku z powyższym genocentryzm, jako tezę filozoficzną dotyczącą obszaru genetyki molekularnej, można rozumieć dwojako. Wskazuje, iż: (i) główną rolę przyczynową w molekularnych

28 Metafora ta została przez A. Rosenberga i P.M. Rosoffa zrekonstruowana na podstawie wcześniejszej metafory Richarda C. Lewontina, która zostanie później przedyskutowana.

29 P.M. Rosoff, A. Rosenberg, How Darwinian Reductionism Refutes Genetic Determinism, Studies in History and Philosophy of Science Part C 37(2006)1, 127 (tłum. A.A.Z.): „The latter directs all aspects of the project, while the former do the actual building on the master builder's instructions. It's the master builder who takes credit or blame for the resulting wall; every one else was just following orders. Unless of course the wall was built on ground unsuitable for brick walls, in which case some other supervisory authority takes the blame. And of course if there is a general contractor who chose the master bricklayer, or supplied the bricks without the master bricklayer's consent, and told him how to design the brickwork better, then perhaps the praise or blame accrues to this person. In our story the bricks and the ground the wall is built on take the role of the environment, and the genes play all the other roles". 
mechanizmach ewolucyjnych i rozwojowych pełnią geny lub (ii) na gruncie mechanizmów ekspresji genów należy zjawiska ewolucyjne oraz rozwojowe wyjaśniać. Teza (i) ma charakter przedmiotowy. Natomiast teza (ii) stanowi pewną dyrektywę adekwatnego wyjaśniania zjawisk biologicznych. Niemniej taka rekonstrukcja zjawisk genetycznych oraz postaw badawczych biologów jest nazbyt uproszczona - w dalszej części tekstu zostaną wskazane argumenty.

\section{PROBLEMY GENOCENTRYZMU}

Zasadnicze problemy związane $\mathrm{z}$ kwestią przyczynowości w kontekście genetyki zaczęły pojawiać się wraz z pewnymi anomaliami w obserwowanym zachowaniu i mechanizmach, jakim podlegają struktury DNA. Pojęcie genu wypracowane na bazie badań J. Watsona i zwłaszcza F. Cricka zrekonstruowane zostało na gruncie filozofii biologii jako neoklasyczna koncepcja genu. Jednakże niezwykle szybko przestała odpowiadać obserwowanym zjawiskom - jeszcze w latach 70. XX wieku zaczęto analizować zjawisko odwrotnej transkrypcji przy badaniu mechanizmów namnażania HIV. Jak twierdzi James A. Shapiro, istnieje spora gama odkryć dotyczących mechanizmów DNA, które stanowią duże wyzwanie dla centralnego dogmatu F. Cricka, są to przykładowo: posttranskrypcyjna obróbka RNA, odkrycie katalitycznego RNA, transkrypcja genomiczna, posttranslacyjna modyfikacja białek, hipoteza dotycząca prionów (jako namnażających się białek), białek mutagennych, ${ }^{30}$. Wiele jednak wskazuje na to, że teza J.A. Shapiro jest nazbyt mocna, natomiast ewentualna falsyfikacja centralnego dogmatu zależy przede wszystkim od tego, jak w sformułowaniu F. Cricka scharakteryzowane zostanie pojęcie informacji oraz sposób funkcjonowania DNA. J.A. Shapiro

30 J.A. Shapiro, Revisiting the Central Dogma in the 21st Century, Annals of the New York Academy of Sciences 1178(2009)1, 6-28; J.A. Shapiro, Evolution: a View From the 21st Century, Upper Saddle River, New Jersey 2011. 
argumentuje, iż centralny dogmat traktuje różne rodzaje kwasów nukleinowych niczym pamięć typu ROM (read only memory). Warto jednak zauważyć, że F. Crick raczej nie odnosi się wprost do kwestii modyfikacji różnych struktur kwasów nukleinowych, zakodowanej informacji, przez czynniki pozagenetyczne, lecz wskazuje kierunek przepływu zakodowanej informacji od kwasu nukleinowego do białek - nie zaobserwowano bowiem, aby jakaś struktura aminokwasu została zakodowana z powrotem do postaci kwasu nukleinowego ${ }^{31}$. Niemniej przytoczone przykłady z pewnością sygnalizują, iż perspektywa molekularna, zwłaszcza w kontekście hipotezy sekwencyjnej, jest nazbyt uproszczona. Natomiast interpretacja J.A. Shapiro jest do pewnego stopnia zasadna w zakresie genocentryzmu, traktującego DNA jako właśnie wyróżniony czynnik sprawczy.

$\mathrm{Na}$ marginesie tej dyskusji ważną kwestię podnosi także Evelyn Fox Keller w kontekście znaczenia genów dla praktyki badawczo-medycznej. Zwraca ona uwagę, że pomimo rozpoznania wielu chorób dziedzicznych ${ }^{32}$, związanych $z$ dysfunkcją jakiejś sekwencji genetycznej, to badanie (rozpoznanie) całego procesu chorobowego dotyczy bardzo złożonego układu zaledwie zapoczątkowanego przez dysfunkcyjny gen. W związku z tym proces leczenia jest w wielu przypadkach niezależny względem odpowiedzialnej struktury genetycznej. Bardziej prawdopodobna jest ingerencja farmakologiczna skierowana w jakiś mechanizm na poziomie układu wyższego poziomu ${ }^{33}$.

Richard C. Lewontin w pracy The Analysis of Variance and the Analysis of Causes zwraca uwagę na to, iż wybranie genów jako specjalnych

31 A.S. Wilkins, Book Review: Evolution: a View From the 21st Century, Genome Biology and Evolution, 4(2012)4, 2-3.

32 E.F. Keller odnosi się akurat do przykładu fenyloketonurii.

33 E.F. Keller, Genes as Difference Makers, w: Genetic Explanations, red. S. Krimsky, J. Gruber, Cambridge, Massachusetts 2013, 34-42. 
jednostek przyczynowych jest nieuzasadnione ${ }^{34}$; konstruuje on, oryginalną, metaforę budowania muru: „Jeśli dwie osoby układają cegły w celu wybudowania muru, możemy całkiem rzetelnie zmierzyć ich wkład, licząc ile każdy z nich ułożył cegieł; jeżeli jednak jedna z osób miesza zaprawę, druga zaś kładzie cegły, absurdalny byłby pomiar ich ilościowego wkładu poprzez mierzenie liczby cegieł i zaprawy" ${ }^{35}$.

Wraz z krytyką R.C. Lewontina sformułowana została propozycja nazywana Causal Democracy Thesis (resp. CDT, teza parytetu przyczynowego). Proponowane jest wzięcie pod rozwagę bardziej holistycznej perspektywy wobec procesów molekularnych. W ramach CDT zakwestionowana zostaje specjalna rola genów w łańcuchach przyczynowych jako po prostu bezzasadna i arbitralna. Ta niejednoznaczność przyczyn staje się wyraźniejsza, gdy rozpatruje się procesy zachodzące na poziomie molekularnym między ekspresją genu a przypuszczalnym fenotypem. Przykładowo, gdy w całą tę sieć zależności włączone zostaną także procesy epigenetyczne, konstytuujące jakieś pozagenetycznie dziedziczone efekty fenotypowe (rozumiane szeroko).

Wydaje się, iż ważnym zarzutem wobec propozycji pełnej równości przyczyn jest w zasadzie trudność realizacji tego postulatu z powodu ograniczeń technicznych i poznawczych ${ }^{36}$. W kwestii badań układów złożonych i otwartych (wymieniających, w szerokim sensie, informację $\mathrm{z}$ otoczeniem) potrzebne jest przyjęcie jakiegoś

34 Krytyka R.C. Lewontina jest co prawda szersza, dotyczy bowiem także różnych postaci interakcjonizmu; ale samo pojęcie interakcjonizmu jest na ten moment na tyle rozmyte, że kwestia ta nie będzie podejmowana - przy odpowiedniej interpretacji każda z omawianych w tym tekście koncepcji mogłaby zostać uznana za interakcjonistyczną.

35 R.C. Lewontin, The Analysis of Variance and the Analysis of Causes, International Journal of Epidemiology 35(2006)3, 521 (tłum. A.A.Z): „if two men lay bricks to build a wall, we may quite fairly measure their contribution by counting the number laid by each; but if one mixes the mortar and the other lays the bricks, it would be absurd to measure their relative quantitative contributions by measuring the volumes of bricks and of mortar".

36 Aczkolwiek wraz ze wzrostem mocy obliczeniowej komputerów, taka cyfrowa obróbka złożonych zjawisk biologicznych staje się coraz bardziej prawdopodobna. 
kryterium ograniczającego układ podlegający badaniu. Kryterium, które nie prowadziłoby do uwzględniania przyczyn działających w sposób niebezpośredni na badany układ. Innymi słowy powinien to być układ wyidealizowany. Na bazie CDT zbudowana została interesująca perspektywa badawcza nazywana Developmental System Theory (resp. DST; systemowa teoria rozwoju).

Należy jednak zwrócić uwagę, że analogiczny problem stawiany jest wobec stanowiska genocentryzmu. Jason Robert wskazał na niezwykle istotną kwestię, jaką jest nazbyt uproszczona heurystyka idąca za genocentryzmem. Upraszczanie kontekstu zjawisk, które mogą być istotne biologicznie na różnych poziomach organizacji, może doprowadzić do fałszywych wniosków. J. Robert wskazuje, że badania prowadzone na wyizolowanych niciach DNA mogą być nazbyt wyabstrahowane, bowiem w takiej formie istnieją wyłącznie w warunkach laboratoryjnych. Jeżeli zatem kontrola kontekstu, w jakim DNA działa, polega na usunięciu tego kontekstu, należy zapytać, jaka istnieje pewność odnośnie stopnia adekwatności wyników tych analiz $z^{37}$.

W związku z tym teza genocentryzmu nakładająca warunki adekwatności na wyjaśnienia, odwołujące się do mechanizmów wyłącznie genetycznych, nie jest zadowalająca dla zwolenników alternatywnego podejścia. Prawdopodobnie także taka perspektywa nazbyt upraszczająco uchwytuje cały proces badawczy i wyjaśnienia zjawisk biologicznych (np. w kontekście uwag E. Fox Keller dotyczących badań biomedycznych).

\section{GENOCENTRYZM W KONTEKŚCIE EVO-DEVO}

Nakreślone uprzednio problemy znalazły swój wyraz w obszarze badań z zakresu ewolucyjnej biologii rozwoju (evolutionary developmental

37 J.S. Robert, Embryology, Epigenesis and Evolution, Cambridge 2004, 1-20. 
biology; resp. evo-devo38). Dyscyplina ta jest raczej pewnym nowym integrującym sposobem myślenia o mechanizmach ewolucyjnych i rozwojowych - w głównej mierze na poziomie molekularnym i makromolekularnym. Istnieje przynajmniej kilka różnych prób zdefiniowania tej dyscypliny, z tego powodu trudno byłoby wskazać jakiś twardy rdzeń teoretyczny i określenie tej perspektywy jako dojrzałej dyscypliny naukowej. Evo-devo stanowić ma przede wszystkim próbę scalenia biologii ewolucyjnej z biologią rozwoju.

J. Robert proponuje trzy ogólne założenia, które stoją za evo-devo: (i) przyjęcie hierarchicznej struktury rozwoju i ewolucji (od skali mikro do skali makro), (ii) potrzebę skoncentrowania badań nad związkami między genotypem a rozwijającym się fenotypem (szeroko pojętym) oraz (iii) przekonanie, że analiza procesów rozwojowych, ich mechanizmów i ich ewolucji, polepsza naszą wiedzę zarówno z zakresu biologii rozwoju oraz biologii ewolucyjnej ${ }^{39}$.

Charakterystyka proponowana przez J. Roberta jest bardzo szeroka, ale jej pojemność w tym wypadku to zdecydowana zaleta. Evo-devo można rozpatrywać $\mathrm{z}$ perspektywy badawczej zarówno genocentryzmu, jak i odwoływać się do tezy parytetu przyczynowego, ponadto odnosić się może do dowolnego podejścia teoretycznego, którego celem jest integracja tych dwóch dyscyplin.

Pewne argumenty (częściowo przedstawione we wcześniejszej części tekstu) przemawiają jednak za tym, aby podjąć wysiłek porzucenia ram badawczych stawiających geny $w$ centrum zainteresowania i rozważenia mniej lub bardziej radykalnych form CDT - ewolucyjna biologia rozwoju wydaje się najlepszym polem do rozpatrzenia tych zagadnień.

38 W starszych publikacjach można spotkać się także ze skrótem EDB, zob. J.S. Robert, Developmental Systems and Animal Behaviour, Biology and Philosophy 18(2003), 477-89.

39 Tłumaczenie na podstawie: J. S. Robert, How Developmental Is Evolutionary Developmental Biology?, Biology and Philosophy 17(2002), 591-611. 


\section{EVO-DEVO ${ }_{\text {GEN }}$}

Jedną ze znaczących prób refleksji nad evo-devo była mocno zachowawcza propozycja Seana Carrolla, który rozważał tę dyscyplinę jako zajmującą się porównaniami genów rozwojowych wśród różnych gatunków oraz mechanizmów pozagenetycznych regulujących te geny. Stoi za tym przekonanie, iż wiele gatunków dzieli część tych samych genów lub przynajmniej ich homologii. Evo-Devo ${ }_{\mathrm{GEN}}{ }^{40}$ wskazuje optykę ograniczoną do tzw. genetycznego zestawu narzędziowego (genetic tool kit) organizmów. W tym kontekście, zdaniem S. Carrolla, największe znaczenie w procesie rozwojowym ma wyróżniona klasa genów homeotycznych (tzw. hox genes, homeobox genes), które są wspólne wielu organizmom - zostały zidentyfikowane wśród kręgowców, jak i bezkręgowców. Odpowiednia regulacja ich ekspresji natomiast pozwala osobnikowi rozwijać się od stadium zarodkowego do samodzielnie egzystującego osobnika ${ }^{41}$.

Perspektywa ta jednakże wciąż przyjmuje nadrzędną rolę genów w kontekście mechanizmów ewolucyjnych oraz rozwoju, pomimo wzięcia pod uwagę procesów wpływających na działanie wyróżnionej klasy struktur genetycznych. Jest to spowodowane tym, że za argumentem S. Carolla stoi tradycyjne dla genocentryzmu przeświadczenie o specjalnej roli kodu genetycznego; sam autor wprost prezentuje to przekonanie pisząc: „każdy wie, że geny muszą znajdować się w centrum zagadki zarówno rozwoju [organizmów - dop. A.A.Z], jak i [ich] ewolucji” ${ }^{2}$. Pomijana jest zatem cała klasa zagadnień związanych $\mathrm{z}$ dziedziczeniem pozagenetycznym postulowanym przez zwolenników bardziej radykalnych podejść.

40 Nazwę zaproponowano w: A. Benítez-Burraco, V.M. Longa, Evo-Devo - of Course, but Which One? Some Comments on Chomsky's Analogies Between the Biolinguistic Approach and Evo-Devo, Biolinguistics 4(2010), 314-316.

41 S.B. Carroll, Endless Forms Most Beautiful, New York 2005.

42 Tamże, 38 (tłum. A.A.Z): „Everyone knew that genes must be at the center of the mysteries of both development and evolution". 
Koncepcja, którą przedstawia S. Carroll, jest bardzo tradycyjnym poglądem za tym, aby rozpatrywać geny jako jednostki stanowiące schemat rozwoju osobnika oraz program jego rozwoju, który zależy wyłącznie od układów tych genów oraz sposobu ich ekspresji - kontrolowanego przez czynniki pozagenetyczne. Jednakże ich znaczenie jest w tym obrazie marginalne, ponieważ za wszystkimi znaczącymi zjawiskami i tak stoją geny. Idea ta mieści się w ramach propozycji A. Rosenberga i P. Rosoffa nadając genom także główną rolę eksplanacyjną w procesie badawczym.

\section{DEVELOPMENTAL SYSTEM THEORY}

Development System Theory została oparta, częściowo, na Lewontinowskiej tezie o parytecie przyczynowym - przynajmniej w kontekście poziomu molekularnego. Jak zostało wcześniej zaznaczone jest to niegenocentryczna, a właściwie anty-genocentryczna, propozycja programu badawczego z zakresu ewolucyjnej biologii rozwoju; J. Robert wskazuje, już w tytule swojej książki, iż głównym mottem tego kierunku jest wzięcie problemu rozwoju na poważnie (taking development seriously), w oderwaniu od klasycznego myślenia o roli DNA.

DST opiera się na podstawowym założeniu, że proces rozwoju nie jest zdeterminowany w jakiś ściśle określony sposób przez układ genetyczny, gdyż takie ujęcie byłoby, jak argumentował R.C. Lewontin, arbitralne. Proces ten powinien być postrzegany jako seria wzajemnych interakcji i transformacji różnych struktur genetycznych i pozagenetycznych oraz emergencji nowych struktur. S. Oyama, P. Griffiths oraz Russell D. Gray rekonstruują kilka ważnych punktów wiążących zagadnienia ewolucyjne i rozwojowe w ramach tej perspektywy ${ }^{43}$ :

43 Na podstawie S. Oyama, P.E. Griffiths, R.D. Gray, Introduction: What Is Developmental Systems Theory?, w: Cycles of Contingency, red. S. Oyama, P.E. Griffiths, R.D. Gray, Cambridge, Massachusetts 2001, 1-12. 
(i) istnieje wiele niezależnych przyczyn działających wspólnie na rozwijający się organizm, zaś czynniki genetyczne i środowiskowe to wyłącznie jedna z możliwości ich ujęcia;

(ii) istotny jest kontekst i stan układu, gdyż każda z przyczyn jest uwarunkowana stanem całego układu;

(iii) rozszerzenie pojęcia dziedziczności, które odnieść należy do szerokiego wachlarza zasobów wpływających na cykl życiowy organizmu;

(iv) rozwój należy postrzegać jako rekonstrukcję, ponieważ ani cechy, ani reprezentacje tych cech (w kodzie DNA) nie są przekazywane potomstwu, lecz cechy (w szerokim sensie) są rekonstruowane podczas rozwoju potomstwa;

(v) proces rozwoju nie odbywa się za pośrednictwem jakiegoś głównego czynnika (genów), lecz kontrola rozwoju rozproszona jest w ramach wielu układów - również niegenetycznych;

(vi) ewolucję należy rozpatrywać jako system oddziałujących wzajemnie na siebie organizmów i środowiska ${ }^{44}$.

Przywołując uprzednio podane ramy konceptualne dla evo-devo zaproponowane przez J. Roberta ${ }^{45}$, wydaje się, że należy punkt (ii) rozszerzyć o związki między genotypem a czynnikami pozagenetycznymi oraz rozwijającym się fenotypem, co pozwoli lepiej odnieść tę konceptualizację do DST. Istotny jest także punkt (i), który sugeruje, że właśnie koncepcja różnych poziomów organizacji materii może wspomóc ograniczanie istotnych przyczyn w badaniu złożonych układów.

Propozycja rekonstrukcji evo-devo z perspektywy DST może pozwolić na interesujący ogląd filozoficzny na część zagadnień. Jak

44 Punkt ten w największym akurat stopniu odnosi się do problemu ewolucji w klasycznym sensie - w ramach sporu o poziom działania mechanizmów ewolucyjnych.

45 (i) Hierarchiczna natura rozwoju i ewolucji, (ii) badania nad związkami genotypu i rozwijającego się fenotypu oraz (iii) przekonanie dotyczące rozwoju wiedzy zarówno z biologii rozwoju, jak i biologii ewolucyjnej. 
sugeruje J. Robert ${ }^{46}$, ciekawą perspektywą jest rozpatrywanie chociażby roli zjawisk epigenetycznych nie jako prostego systemu kontroli ekspresji genów w rozwoju osobniczym, lecz wzięcia pod uwagę struktury przyczynowej procesu rozwojowego jako sieci zależności. Mogłoby to pomóc w wydzieleniu pewnych modułów genetycznych oraz poza-genetycznych, podlegających procesom rozwojowym zwłaszcza rozpatrzenie w takim kontekście klasy hox genes.

Trzeba zaznaczyć, że Developmental System Theory nie jest jeszcze tezą najradykalniejszą w świetle ambicji związanych z evo-devo do integracji biologii ewolucyjnej i biologii rozwoju oraz rozpoznanych anomalii na gruncie klasycznej genetyki molekularnej (na które zwrócił uwagę przywoływany wcześniej J.A. Shapiro). DST rozpatruje jedynie zagadnienie rozwoju jako równie istotny składnik teoretyczny, co procesy genetyczne. Bardziej rewolucyjne interpretacje w ramach rozszerzonej syntezy ewolucyjnej (extended evolutionary synthesis) celują nie tylko w tezę genocentryzmu, ale w całość paradygmatu ewolucyjnego.

Niewątpliwie nie-genocentryczne podejścia stanowią ciekawy projekt filozoficzny. Jednakże wydaje się, że istnieje pewna problematyczność w obrębie tych propozycji. Trudno bowiem ustalić, czy przedstawione powyżej stanowisko ma charakter opisowy, czy też stanowi raczej próbę konstrukcji odrębnego programu badawczego do wdrożenia w praktykę badawczą. Genocentryzm chociaż jest krytykowany z wielu stron, jest jednakże wyłącznie próbą rekonstrukcji praktyk badawczych biologów na gruncie filozofii przyrody i filozofii nauki. Sytuacja związana $z$ alternatywnymi propozycjami podejścia do genetyki i dziedziczności jest związana z dużym i aktywnym zaangażowaniem części filozofujących biologów w ten dyskurs (np. Eva Jablonka wraz z Marion Lamb, czy J.A. Shapiro). W związku z tym trudno jest wskazać jasną granicę między filozoficzną interpretacją

46 J.S. Robert, Embryology, Epigenesis and Evolution, Cambridge 2004. 
przedmiotu badań i praktyki naukowej, a nastawieniem na zmianę paradygmatu.

\section{ZAKOŃCZENIE}

Zagadnienie genocentryzmu jest szczególnie szeroko poruszane $\mathrm{w}$ refleksji nad naukami biologicznymi; przedstawione w niniejszym tekście stanowiska $\mathrm{z}$ całą pewnością nie wyczerpują bogatych argumentów za i przeciwko tezie o specjalnej roli genów.

Istotnym wnioskiem płynącym z przedstawionych tutaj stanowisk dotyczących genetyki jest to, że idea DNA, jako swoistego centrum dowodzenia całym układem biologicznym, nie jest oczywista. Słabość takiego prostego schematu uwidacznia się w kontekście zarówno praktyki badawczej - wymagającej częstokroć uwzględniania czynników pozagenetycznych (zwłaszcza w ramach nauk biomedycznych) dla adekwatnego wyjaśnienia zjawiska lub problemu badawczego. Ale także z perspektywy badań fundamentalnych na gruncie nauk biologicznych.

Nie jest tak, że propozycja genocentryczna odrzuca w zupełności interakcje między DNA a strukturami pozagenetycznymi, ale odnośnie roli genów wnioskuje głównie na podstawie prowadzonych dotychczas badań koncentrujących się po prostu na genach. Perspektywa genocentryczna $\mathrm{w}$ kontekście zjawisk molekularnych nie wydaje się w pełni odpowiadać na dynamiczne zmiany konceptualne zachodzące na gruncie biologii molekularnej. Istotności DNA dla zjawisk biologicznych nie można zakwestionować, jednakże nadawanie temu obiektowi specjalnej roli wyjaśniającej i przyczynowej może być poprawne w pewnych, ograniczonych, kontekstach badawczych.

Propozycję teoretyków i filozofów biologii, dotyczącą zdecydowanie bardziej holistycznego spojrzenia na kwestię przyczynowości, należy traktować jako postulat innej perspektywy badawczej. Propozycji zdolnej do zniwelowania części problemów wynikłych z tradycyjnego rozpoznawania roli materiału genetycznego. Zwłaszcza 
koncepcja evo-devo wydaje się mocniej ubogacić wiedzę dotyczącą zależności na poziomie molekularnym, przyjąwszy perspektywę bardziej systemową. Ważnym problemem wynikającym $z$ takich holistycznych idei jest to, że utracone może zostać wygodne narzędzie analityczne związane $z$ dyskretnością genów. Jak zostało zaznaczone wcześniej, geny w całej tradycji są charakteryzowane jako struktury jednostkowe. Istnieją zasadne wątpliwości odnośnie ich adekwatnego wyznaczania ${ }^{47}$, niemniej stanowią istotną podstawę dla całego paradygmatu ewolucyjno-biologicznego ${ }^{48}$.

Zarówno genocentryzm, jak i propozycje systemowe odnoszą się w dużym stopniu do różnych perspektyw badawczych, które można uznać za niewspółmierne. Przede wszystkim ze względu na konceptualizacje pojęcia genu. W ramach stanowiska genocentrycznego termin gen ma ogromne znaczenie i charakteryzowany jest zazwyczaj właśnie w sposób klasyczny. Na gruncie DST pojęcie genu traci zaś na znaczeniu, bliska wydaje się być interpretacja Richarda Buriana. Autor ten twierdzi, że na gruncie biologii molekularnej trudno mówić o pojęciu genu per se-znaczenie genu w zakresie tej dyscypliny odnosi się do mnogości różnych struktur, pełniących różne funkcje. $Z$ tego powodu należy raczej mówić o pewnych strukturach genetycznych ze słownika biologii molekularnej (np. cistronach, eksonach, itp.), zaś pojęcie genu uznać za pełniące rolę wygodnego odniesienia do tych różnych struktur ${ }^{49}$. Zgodnie z propozycją DST należy rozpatrywać relację pomiędzy materiałem genetycznym (o danej funkcjonalności

47 Por. K.C. Stotz, P.E. Griffiths, R. Knight, How Biologists Conceptualize Genes: an Empirical Study, Studies in History and Philosophy of Science Part C 35(2004)4, 647-673.

48 Zostało wielokrotnie wskazane w literaturze, że aktualne wyniki badań nie pozwalają bezstratnie przenieść darwinowskiej teorii ewolucji na poziom molekularny. Zagadnienie to związane jest z całą problematyką redukcji; podnoszone jest m.in. w A. Rosenberg, Darwinian Reductionism, Chicago, Illinois 2006.

49 Chociaż sam autor postuluje zupełne odrzucenie tego terminu w zakresie genetyki, por. R.M. Burian, The Epistemology of Development, Evolution, and Genetics, Cambridge 2005, 166-178. 
lub strukturze) a kontekstem pozagenetycznym - innymi słowy badać sposoby interakcji pomiędzy nimi.

Aktualny status evo-devo wydaje się być niejednoznaczny. Głównym przedmiotem tej dyscypliny jest $\mathrm{z}$ pewnością podjęcie zagadnienia rozwoju i wpływ tego zjawiska na pojawianie się i zmienność fenotypów. Zagadnienie to wymyka się interpretacjom genocentrycznym ze względu na to, że kontekst pozagenetyczny ma ogromne znaczenie dla wyjaśniania tych procesów. Tezy systemowe, chociaż niedoskonałe, stanowią interesujący punkt rozpatrywania tych zagadnień z perspektywy filozofii biologii.

\section{BIBLIOGRAFIA}

Benítez-Burraco A., Longa V.M., Evo-Devo - of Course, but Which One? Some Comments on Chomsky's Analogies Between the Biolinguistic Approach and Evo-Devo, Biolinguistics 4(2010), 314-316.

Burian R.M., On Conceptual Change in Biology: the Case of the Gene, w: Evolution at a Crossroads, red. D.J. Depew, B.H. Weber, MIT Press, Cambridge, Massachusetts 1985, 21-42.

Burian R.M. The Epistemology of Development, Evolution, and Genetics, Cambridge University Press, Cambridge 2005.

Carroll S.B. Endless Forms Most Beautiful, W. W. Norton \& Company, New York 2005.

Crick F.H.C., Central Dogma of Molecular Biology, Nature 227(1970), 561-63.

Crick F.H.C., On Protein Synthesis, Symposia of the Society for Experimental Biology 12(1958), 138-63.

Dawkins R. Samolubny gen, tłum. z ang. M. Skoneczny, Wydawnictwo Prószyński i S-ka, Warszawa 2012.

Deichmann U., Gemmules and Elements: on Darwin's and Mendel's Concepts and Methods in Heredity, w: Darwinism, Philosophy, and Experimental Biology, red. U. Deichmann, A.S. Travis, Springer Netherlands, Dordrecht 2011, 31-58.

Garvey B., Philosophy of Biology, Acumen, Stocksfield 2007, 1-29.

Gleick J., Informacja, tłum. z ang. G. Siwek, Wydawnictwo Znak, Kraków 2012. Habermas J., Przysztość natury ludzkiej, tłum. z niem. M. Łukasiewicz, Wydawnictwo Naukowe Scholar, Warszawa 2003. 
Hull D.L., Informal Aspects of Theory Reduction, w: PSA 1974, red. R.S. Cohen, C.A. Hooker, A.C. Michalos, J.W. van Evra, Springer Science \& Business Media, Dordrecht 1976, 653-670.

Keller E.F., Genes as Difference Makers, w: Genetic Explanations, red. S. Krimsky, J. Gruber, Harvard University Press, Cambridge, Massachusetts 2013, 34-42. Kemeny J.G., Oppenheim P., On Reduction, Philosophical Studies 7(1956)1, 6-19. Lewontin R.C., The Analysis of Variance and the Analysis of Causes, International Journal of Epidemiology 35(2009)3, 520-25.

Magner L.N., A History of the Life Sciences, Marcel Dekker, Inc., New York 2002. Mayr E., To jest biologia, tłum. z ang. J. Szacki, Prószyński i S-ka, Warszawa 2002. Oyama S., Griffiths P.E., Gray R.D., Introduction: What Is Developmental Systems Theory?, w: Cycles of Contingency, red. S. Oyama, P.E. Griffiths, R.D. Gray, The MIT Press, Cambridge, Massachusetts 2001, 1-12.

Portin P., The Concept of the Gene: Short History and Present Status, The Quarterly Review of Biology 68(1993)2, 173-223.

Robert J.S., Developmental Systems and Animal Behaviour, Biology and Philosophy 18(2003), 477-89.

Robert J.S., Embryology, Epigenesis and Evolution, Cambridge University Press, Cambridge 2004.

Robert J.S., How Developmental Is Evolutionary Developmental Biology?, Biology and Philosophy 17(2002), 591-611.

Rosenberg A., Darwinian Reductionism, University of Chicago Press, Chicago, Illinois 2006.

Rosenberg A., Defending Information-Free Genocentrism, History \& Philosophy of the Life Sciences 27(2005)3, 345-59.

Rosoff P.M, Rosenberg A., How Darwinian Reductionism Refutes Genetic Determinism, Studies in History and Philosophy of Science Part C 37(2006)1, 122-35.

Sarkar S., Genetics and Reductionism, Cambridge University Press, Cambridge 1998. Schaffner K.F., Approaches to Reduction, Philosophy of Science 34(1967), 137-47.

Schaffner K.F., Discovery and Explanation in Biology and Medicine, University of Chicago Press, Chicago, Illinois 1993.

Shapiro J.A., Evolution: a View From the 21st Century, FT Press Science, Upper Saddle River, New Jersey 2011.

Shapiro J.A., Revisiting the Central Dogma in the 21st Century, Annals of the New York Academy of Sciences 1178(2009)1, 6-28.

Stotz K.C., Griffiths P.E., Knight R., How Biologists Conceptualize Genes: an Empirical Study, Studies in History and Philosophy of Science Part C 35(2004)4, 647-73. 
Waters C.K., Genes Made Molecular, Philosophy of Science 61(1994)2, 163-85.

Wilkins A.S., Book Review: Evolution: a View From the 21st Century, Genome Biology and Evolution 4(2012)4, 423-26.

\section{CONTROVERSY OVER GENE-CENTRISM IN THE PHILOSOPHY OF BIOLOGY}

Abstract. The roots of the gene-centric view should be sought in a dynamic development of the nineteenth- and twentieth-century genetics - especially the modern evolutionary synthesis and molecular genetics. Behind this idea is a thesis that in biological sciences explanations that refer to genetic factors are privileged. In turn, the most important assumption of this thesis is that at the molecular level the genes and genetic code play a special role in determining the development of an organism.

Although the gene-centric conception is one of the cornerstones of modern evolution theory, it has little interest in broader problems of development. Therefore, in recent years there has been a shift towards an alternative perspective stressing the importance of non-genetic factors in explaining the phenomena and processes of biological development.

Especially interesting in this context are arguments and ideas purporting to reject the thesis of a special role of genes and genetic code, particularly in the field of evolutionary developmental biology. An evo-devo context seems interesting because of its ambition to integrate developmental biology with evolutionary biology.

Keywords: natural philosophy, philosophy of science, philosophy of biology, genetics, gene-centrism, evo-devo

\footnotetext{
Aleksander A. Ziemny

aleksander.ziemny@amu.edu.pl

Uniwersytet im. Adama Mickiewicza w Poznaniu, Instytut Filozofii

Szamarzewskiego 89, 60-568 Poznań
}

DOI: 10.21697/spch.2017.53.1.13 